Ключевые слова: давность наступления смерти, стекловидное тело, методы диагностики, судебно-медицинская экспертиза.

\title{
VITREOUS BODY AS OBJECT OF RESEARCH IN FORENSIC MEDICAL EXPERTISE
}

\author{
Bachinsky V.T., Sarkisova Yu.V.
}

Summary. The article presents an analysis of modern literature on the structure and structural features of the vitreous body of the human eye, as well as the possibility of its application as an object of investigation in establishing the time since death.

Key words: time since death, vitreous body, diagnostic methods, forensic medical examination.

DOI: https://doi.org/10.24061/2707-8728.1.2018.22

УДК 616-005.1-07:340.62

\section{СУЧАСНИЙ СТАН СУДОВО-МЕДИЧНОЇ ДІАГНОСТИКИ ГОСТРИХ КРОВОВТРАТ}

\author{
Бачинський В.Т., Сивокоровська А-В.С. \\ ВДНЗ України «Буковинський державний медичний університет»
}

\begin{abstract}
Резюме. У статті наведено огляд літератури щодо існуючих методів визначення гострої крововтрати при судово-медичному дослідженні трупа, розглянуто сучасний стан проблеми та перспективи іiї вирішення.

Ключові слова: гостра крововтрата, судово-медична експертиза, лазерна поляриметрія.
\end{abstract}

Вступ. Крововтрата - є однією з причин смерті, що часто зустрічається у практиці лікаря судово-медичного експерта. Щорічно ми спостерігаємо тенденцію зростання смертельних випадків травматичного ушкодження 3 крововтратою (К). При гострій крововтраті (ГК) кров у великій кількості витікає назовні, в інших випадках накопичується у порожнинах тіла, або ж відбувається поєднання обох видів К.

ГК зі смертельним наслідком найчастіше розвивається внаслідок ушкодження магістральних судин, серця чи паренхіматозних органів. Провідна роль у патогенезі порушення функціонування організму при К належить гемодинамічним розладам по типу судинної недостатності. Недостатність кровообігу тягне за собою порушення кровопостачання органів та систем організму з подальшим розвитком кисневого голодування. Смерть настає внаслідок паралічу дихального центру. Серце зупиняється одночасно або через деякий час [1].

Для задовільного функціонування організму та внутрішніх органів велике значення має збереження в організмі сталого об'єму циркулюючої крові. В нормальних умовах у чоловіків об'єм циркулюючої крові складає 70 мл/кг, проте 3 віком зменшується до 65 мл/кг, що приблизно складає 7\% маси тіла чоловіка. У жінок ця величина складає 55-60 мл/кг (6,5\% маси тіла жінки), проте жінки менш чутливі до К ніж чоловіки [2]. При зменшенні такого об'єму, наступає централізація кровообігу - переважне кровопостачання життєво важливих органів за рахунок недостатнього кровопостачання інших.

Велика кількість крові, виявлена в порожнинах та внутрішніх органах трупа, не є визначальною для встановлення темпу К, iї кратності, а також визначення тривалості термінального процесу [3]. При пораненні м'яких тканин iз ушкодженням великих кровоносних судин зазвичай розвивається ГК, що найчастіше призводить до смерті [4]. Смерть може настати навіть при ГК у незначній кількості - об'ємом близько 500 мл. У той самий час повільна К, об'ємом 2л і більше, оцінюється як небезпечна для життя, проте може не бути летальною за рахунок розвитку компенсаторних процесів в організмі.

Провівши огляд та проаналізувавши експериментальні та експертні дослідження, що висвітлені у науковій медичній літературі, видно що деякі автори описують зміни в тканинах головного мозку, серця, легень, нирок та надниркових залоз при К, поєднаній з черепно-мозковою травмою, алкогольною чи наркотичною інтоксикаціями, а також без них $[3,5]$.

До загальних патоморфологічних проявів гострого малокрів’я відносять: наявну різко виражену блідість шкірних покривів тіла, слизових та серозних оболонок; повільне утворення трупних плям і слабкий їх прояв; різко виражене трупне заклякання; блідість, знекровлення внутрішніх органів з глинистим відтінком (печінки, нирки, серця), та суховатістю поверхні розрізу (легені); селезінка зменшена в розмірах, зморщена; мала кількість крові в судинах та порожнинах серця $[6,7]$.

Досить частою ознакою даного патологічного процесу - $\epsilon$ точкові крововиливи під ендокард лівого шлуночка серця (плями Мінакова). П.А. Мінаков вважав, що дані крововиливи виникають у результаті роботи «порожнього» 
серця, коли при недостатній кількості крові у лівому шлуночку серця виникає від’ємний тиск. У наступні роки цю теорію розвивали такі науковці, як Ільїнський С.П. (1947), Десятов В.П. (1951), Штерберг А.І. (1965) та ін. Більшість науковців притримувались думки, що такі екхімози виникають у наслідок розвитку травматичного шоку, який розвинувся в найближчий час після отримання ушкоджень. Десятов В.П. пов'язував утворення субендокардіальних крововиливів 3 анемічною аноксією центральної нервової системи. Дреймане В.К у своїх дослідженнях відмічав наявність екхімозів під ендокард не тільки при травматичному шоці, а й у випадках септичних захворювань, уремії, підвищенні внутрішньо-черепного тиску. Таким чином, описана 100 років тому теорія походження субендокардіальних екхімозів («плям Мінакова»), за даними літературних джерел, викликає сумніви у науковців, хоча їх патогенетичне значення $€$ важливим і досі для встановлення причини та темпу смерті [8].

Науковці вважають за доцільне враховувати морфологічні зміни у внутрішніх органах при ГК, зокрема в інтактних легенях. Так, Н.Г. Давидова прослідковувала динаміку патоморфологічних змін в інтактних легенях при ГК на протязі 30хв після настання смерті. Нею встановлені кількісні показники маси, щільності, водонасичення легень та їх взаємозв'язок з гістологічною картиною легеневої тканини [9].

О.В.Должанський [10], на основі проведених досліджень розробив комплекс морфофункціональних критеріїв ГК, які мають свої особливості на фоні алкогольної та наркотичної інтоксикацій, черепно-мозковій травмі. До таких основних морфологічних критеріїв він відніс: контрактурне пошкодження, хвилеподібну деформацію і дисоціацію кардіоміоцитів; гіпогідратацію головного мозку з іррегулярним типом розподілу тканинної рідини; переважання периваскулярного набряку головного мозку над перицелюлярним набряком; каріоцитоліз нервових клітин головного мозку,

Також О.В.Должанський проводив дослідження з виявлення даних, які допоможуть встановити ознаки повторної К. До таких ознак він відносить: появу гемосидерину, переважання у два рази зернисто-глибчатого розпаду кардіоміоцитів над міоцитолізом серцевого м'яза; виражену експресію маркера апоптозу р53.

Ю.І. Піголкін, О.В. Должанський, А.А. Бичков, А.С. Мосоян та ін. проводили оцінку трупних плям при ГК 3 використанням імуногістохімічної реакції з первинними антитілами до гемоглобіну і фібронектину. В дермі вони виявляли помірно виражену експресію гемоглобіну і фібронектину. Отримані ознаки можуть використовуватись як додаткові судово-медичні критерії посмертного переміщення чи зміни положення трупа в стадії стазу при смерті від ГК.

Окремі наукові дослідження показують динаміку структурних змін синусів лімфатичних вузлів щура 3 використанням методів електронної мікроскопії для визначення ГК з перспективою продовження даних досліджень щодо лімфатичних вузлів людини [11].

Деякі ж автори досліджували вплив смертельної ГК на зміни фосфоліпідів серця за допомогою методів імуноферментного аналізу [12].

Під час розслідування органами дізнання тієї чи іншої справи, часто постає питання про кількість рідкої крові, що утворила ту чи іншу пляму, знаходиться на одязі потерпілого, скільки їі депонувалась у крововиливах. Провівши огляд літературних джерел, більшість робіт висвітлюють практичні рекомендації по отриманні зразків крові із одягу та інших об'єктів $[14,15]$. Всі відомі методи оцінки отриманих даних базуються на визначенні сухого залишку в плямі одягу та перерахування його на рідку кров [15].

Заслуговує уваги робота Л.О. Яланської, що розробила та апробувала деякі методики визначення об'єму втраченої крові на одязі, з поверхонь ран, у крововиливах у м'язи та жирову клітковину [16]. Такі методики базуються на підставі результатів математичного аналізу макро- i мікроскопічних ознак кровопостачання внутрішніх органів, 3 використанням кваліметричного підходу, який грунтується на оцінці ознак ушкодження, що переведені у бали, та для яких розроблені спеціальні тест-таблиці [17].

Висновки. Отже, існуюча інформація про ГК та всі загально прийняті класичні методи, що базуються на використанні гістологічних, гістохімічних, імунологічних методах, при ГК, не можуть повністю задовольнити поставленні питання в судово-медичній експертизі. Аналізуючи отримані нами дані вбачаємо необхідність пошуку новітніх методик визначення судово-медичних критеріїв ГК, що базувались би на класичних методах забору біологічних тканин. Такими методами можуть стати сучасні біофізичні методи, найбільш перспективними з яких, на наш погляд, є оптичні методики із застосуванням лазерного випромінювання $[18,19]$.

Такі методики основані на застосуванні комплексу поляризаційних, матричних, статистичних і кореляційних параметрів лазерних зображень біотканин та рідких середовищ [20,21].

Згідно даного підходу, усі типи біологічних структур представлені у вигляді двокомпонентної аморфноанізотропної матриці, що являє собою сукупність оптично одноосних протеїнових фібрил, що подібні до рідких кристалів та володіють явищем двопроменезаломлення [19,22].

Таким чином, апробовані методики лазерної поляриметрії дають можливість усучаснити судово-медичних підхід діагностики патологічних змін біотканин, визначення давності настання смерті, диференціації патологічних процесів, та можуть отримати своє застосування у визначенні судово-медичних критеріїв ГК.

\section{Література}

1. $\quad$ Громов АП, Науменко ВГ. Судебно-медицинская травматология (руководство). Москва: Медицина; 1977. 368c.

2. Малышев ВД. Интенсивная терапия. Реанимация. Первая помощь. Москва: Медицина; 2000. 464 с. 
3. Должанский ОВ, Бурлакова БУ. Изменения внутренних органов при острой кровопотери в судебномедицинской практике. Судебно-медицинская экспертиза. 2006;4:39-41.

4. Яланська ЛО. Розробка методів визначення об'єму крововтрати при проведенні судово-медичних експертиз. Вісник проблем біології і медицини. 2002;2:93-7.

5. Должанский ОВ, Бурлакова БУ. Изменения головного мозга при острой кровопотере и их судебно-медицинское значение. Судебно-медицинская экспертиза. 2006;5:39-40.

6. Концевич ІО, Михайличенко БВ, редактори. Судова медицина: Підручник для студентів мед. вузів. Київ: Леся; 1997. $656 \mathrm{c}$.

7. Струков АI, Сєров ВВ. Патологічна анатомія. Харків: Факт; 2004. 864 с.

8. Десятов ВП. Судебно-медицинское значение пятен Минакова и некоторые данные к их патогенезу. Томск; 1951. $321 \mathrm{c}$.

9. Давыдова НГ. Судебно-медицинская оценка интактных легких при быстро наступившей смерти от ранений острыми предметами [автореферат]. Санкт-Петербург; 2005. 21 с.

10. Должанский ОВ. Судебно-медицинская оценка острой кровопотери по морфофункциональным изменениям внутренних органов [автореферат]. Москва; 2014. 39 с.

11. Рейхерт ВЭ, Григорьев ВН. Структурные изменения синусов лимфатического узла при острой кровопотери. Архив анатомии, гистологии, эмбриологии. 1991;1:62-6.

12. Долгих ВТ. Влияние острой смертельной кровопотери на постреанимационные изменения фосфолипидов сердца и их предупреждение [Effect of acute lethal hemorrhage on postresuscitation alterations in heart phospholipids and their prophylaxis]. Вопросы медицинской химии. 1991;37(3):9-13.

13. Шмидт ВК, редактор. Вещественные доказательства в судебной медицине. Практическое пособие. Рига: МЗ ЛатССР; 1986. 104 c.

14. Бордонос ТГ, Булыга ЛП. Методика сравнительного исследования текстильных тканей. Киев; 1963. 42 c.

15. Туманов АК. Судебно-медицинское исследования вещественных доказательств. Москва: Госюриздат; 1961. $580 \mathrm{c}$.

16. Яланська ЛО. Судово-медична оцінка гострої крововтрати за особливостями кровонаповнення внутрішніх органів [автореферат]. Київ; 2002. 17 с.

17. Бачинський ВТ. Лазерна спектрофотополяриметрія біологічних тканин людини в розробці об'єктивних критеріїв визначення давності настання смерті та часу утворення гематом [автореферат]. Київ; 2008. 35 с.

18. Ушенко ОГ, Бачинський ВТ, Ванчуляк ОЯ, Беженар ІЛ. Основи лазерної поляриметрії (Патоморфологічні зміни біологічних тканин). Чернівці: Чернівецький національний університет; 2010. 372 с.

19. Гараздюк МС. Метод просторово-частотної фільтрації поляризаційних мап зображень полікристалічних плівок ліквору для визначення давності настання смерті. Судово-медична експертиза. 2017;1:65-73.

20. Handbook of Coherent-Domain Optical Methods. Tuchin VV, editor. 2nd ed. New York: Springer Science+Business Media; 2013. Ushenko YA, Boychuk TM, Bachynsky VT, Mincer OP, Diagnostics of Structure and Physiological State of Birefringent Biological Tissues: Statistical, Correlation and Topological Approaches; p. 107-48.

21. Ванчуляк ОЯ, Ушенко ОГ, Беженар ІЛ. Застосування поляризаційного методу для аналізу пошкоджень біотканин. Буковинський медичний вісник. 2004;8(3-4):300-1.

\section{References}

1. Gromov AP, Naumenko VG. Sudebno-meditsinskaya travmatologiya (rukovodstvo) [Forensic traumatology (manual)]. Moskva: Meditsina; 1977. 368s. (in Russian)

2. Malyshev VD. Intensivnaya terapiya. Reanimatsiya. Pervaya pomoshch' [Intensive therapy. Resuscitation. First aid]. Moskva: Meditsina; 2000. 464 s. (in Russian)

3. Dolzhanskiy OV, Burlakova BU. Izmeneniya vnutrennikh organov pri ostroy krovopoteri v sudebno-meditsinskoy praktike [Changes in internal organs in acute blood loss in forensic practice]. Sudebno-meditsinskaya ekspertiza. 2006;4:39-41. (in Russian)

4. Yalans'ka LO. Rozrobka metodiv vyznachennia ob'iemu krovovtraty pry provedenni sudovo-medychnykh ekspertyz [Development of methods for determining the amount of blood loss during forensic examinations]. Visnyk problem biolohii i medytsyny. 2002;2:93-7. (in Ukrainian)

5. Dolzhanskiy OV, Burlakova BU. Izmeneniya golovnogo mozga pri ostroy krovopotere i ikh sudebno-meditsinskoe znachenie [Brain changes in acute blood loss and their forensic significance]. Sudebno-meditsinskaya ekspertiza. 2006;5:39-40. (in Russian)

6. Kontsevych IO, Mykhailychenko BV, redaktory. Sudova medytsyna: Pidruchnyk dlia studentiv med. vuziv [Forensic Medicine]. Kyiv: Lesia; 1997. 656 s. (in Ukrainian)

7. Strukov AI, Sierov VV. Patolohichna anatomiia [Pathological anatomy]. Kharkiv: Fakt; 2004. 864 s. (in Ukrainian)

8. Desyatov VP. Sudebno-meditsinskoe znachenie pyaten Minakova i nekotorye dannye k ikh patogenezu [Forensic value of Minakov spots and some data on their pathogenesis]. Tomsk; 1951. 321 s. (in Russian)

9. Davydova NG. Sudebno-meditsinskaya otsenka intaktnykh legkikh pri bystro nastupivshey smerti ot raneniy ostrymi 
predmetami [Forensic evaluation of intact lungs with rapid death from wounds from sharp objects] [avtoreferat]. SanktPeterburg; 2005. 21 s. (in Russian)

10. Dolzhanskiy OV. Sudebno-meditsinskaya otsenka ostroy krovopoteri po morfofunktsional'nym izmeneniyam vnutrennikh organov [Forensic medical assessment of acute blood loss based on morphological and functional changes in internal organs] [avtoreferat]. Moskva; 2014. 39 s. (in Russian)

11. Reykhert VE, Grigor'ev VN. Strukturnye izmeneniya sinusov limfaticheskogo uzla pri ostroy krovopoteri [Structural changes in the sinuses of the lymph node in acute blood loss]. Arkhiv anatomii, gistologii, embriologii. 1991;1:62-6. (in Russian)

12. Dolgikh VT. Vliyanie ostroy smertel'noy krovopoteri na postreanimatsionnye izmeneniya fosfolipidov serdtsa i ikh preduprezhdenie [Effect of acute lethal hemorrhage on postresuscitation alterations in heart phospholipids and their prophylaxis]. Voprosy meditsinskoy khimii. 1991;37(3):9-13. (in Russian)

13. Shmidt VK, redaktor. Veshchestvennye dokazatel'stva v sudebnoy meditsine. Prakticheskoe posobie [Physical evidence in forensic medicine]. Riga: MZ LatSSR; 1986. 104 s. (in Russian)

14. Bordonos TG, Bulyga LP. Metodika sravnitel'nogo issledovaniya tekstil'nykh tkaney [Comparative study of textile fabrics]. Kiev; $1963.42 \mathrm{c}$.

15. Tumanov AK. Sudebno-meditsinskoe issledovaniya veshchestvennykh dokazatel'stv [Forensic examination of physical evidence]. Moskva: Gosyurizdat; 1961. 580 s. (in Russian)

16. Yalans'ka LO. Sudovo-medychna otsinka hostroi krovovtraty za osoblyvostiamy krovonapovnennia vnutrishnikh orhaniv [Forensic Medicine Evaluation of the Acute Bloodloss for the particularities of blood supply of inner organs] [avtoreferat]. Kyiv; 2002. 17 s. (in Ukrainian)

17. Bachyns'kyi VT. Lazerna spektrofotopoliarymetriia biolohichnykh tkanyn liudyny v rozrobtsi ob'iektyvnykh kryteriiv vyznachennia davnosti nastannia smerti ta chasu utvorennia hematom [Laser spectrophotopolarimetry of human biological tissues in the elaboration of objective criteria of evaluating the prescription of death coming and the time of hematoma formation] [avtoreferat]. Kyiv; 2008. 35 s. (in Ukrainian)

18. Ushenko OH, Bachyns'kyi VT, Vanchuliak OIa, Bezhenar IL. Osnovy lazernoi poliarymetrii (Patomorfolohichni zminy biolohichnykh tkanyn) [Fundamentals of laser polarimetry (Pathomorphological changes of biological tissues)]. Chernivtsi: ChNU; 2010. 372 s. (in Ukrainian)

19. Harazdiuk MS. Metod prostorovo-chastotnoi fil'tratsii poliaryzatsiinykh map zobrazhen' polikrystalichnykh plivok likvoru dlia vyznachennia davnosti nastannia smerti [Time since deaht estimation by the method of the threedimensionalfrequency polarizing maping filtering of polycrystalline cerebro-spinal fluid films images]. Sudovo-medychna ekspertyza. 2017;1:65-73. (in Ukrainian)

20. Handbook of Coherent-Domain Optical Methods. Tuchin VV, editor. 2nd ed. New York: Springer Science+Business Media; 2013. Ushenko YA, Boychuk TM, Bachynsky VT, Mincer OP, Diagnostics of Structure and Physiological State of Birefringent Biological Tissues: Statistical, Correlation and Topological Approaches; p. 107-48.

21. Vanchuliak OIa, Ushenko OH, Bezhenar IL. Zastosuvannia poliaryzatsiinoho metodu dlia analizu poshkodzhen' biotkanyn [Application of the polarization method for the analysis of biotissue damage]. Bukovyns'kyi medychnyi visnyk. 2004;8(34):300-1. (in Ukrainian)

\title{
СОВРЕМЕННОЕ СОСТОЯНИЕ СУДЕБНО-МЕДИЦИНСКОЙ ДИАГНОСТИКИ ОСТРЫХ КРОВОПОТЕРЬ
}

\author{
Бачинский В. Т., Сивокоровская А-В. С.
}

Резюме. В статье приведен обзор литературы по существующим методам определения острой кровопотери при судебномедицинском исследовании трупа, рассмотрено современное состояние проблемы и перспективы ее решения.

Ключевые слова: острая кровопотеря, судебно-медицинская экспертиза, лазерная поляриметрия.

\section{MODERN STATE OF FORENSIC DIAGNOSTICS OF ACUTE BLOOD LOSS}

\author{
Bachynskyi V.T., Syvokorovska A-V.S.
}

\footnotetext{
Abstract. A review of the literature on existing methods of determination of acute blood loss in the forensic investigation of the corpse, the current state of the problem and prospects for it solution have been analyzed in the article.

Key words: acute blood loss, forensic medical examination, laser polarimetry.
} 